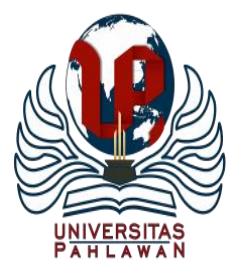

\author{
Jurnal Abdidas Volume 1 Nomor 4 Tahun 2020 Halaman 296 - 305 \\ JURNAL ABDIDAS \\ Community Development Service on Educational and Health Sciences \\ http://abdidas.org/index.php/abdidas
}

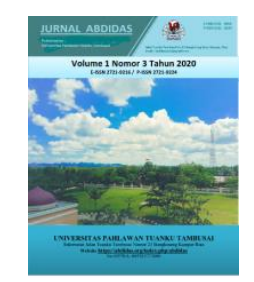

\title{
Hubungan Pengetahuan Dan Sikap Dengan Perilaku Hidup Bersih Dan Sehat Pada Keluarga Di Kelurahan Muara Ciujung Barat Wilayah Kerja Puskesmas Rangkasbitung
}

\author{
Deni Hermawan ${ }^{1}$, Ucu Wandi Somantri ${ }^{2}$ \\ Dinas Kesehatan Lebak ${ }^{1}$ \\ Prodi Kesehatan Masyarakat, Fakultas Sains, Farmasi dan Kesehatan, Universitas Mathla'ul Anwar ${ }^{2}$ \\ E-mail : denihermawan711@gmail.com ${ }^{1} \underline{\text { Ucuancayur@gmail.com }}{ }^{2}$
}

\begin{abstract}
Abstrak
Dengan terciptanya kehidupan masyarakat yang sehat, tentu merupakan modal utama dan aset yang sangat berharga untuk melaksanakan pembangunan. Salah satu cara mewujudkan masyarakat yang sehat adalah dengan menerapkan perilaku hidup bersih dan sehat (PHBS) di lingkungan masyarakat. Tujuan penelitian ini untuk mengetahui faktor-faktor yang mempengaruhi perilaku hidup bersih dan sehat (PHBS) pada keluarga Di Kelurahan Muara Ciujung Barat Wilayah Kerja Puskesmas Rangkasbitung Tahun 2018. Penelitian ini bersifat analitik dengan sampel 107 responden diambil menggunakan teknik simple random sampling. Hasil penelitian diketahui hampir sebagian besar keluarga menerapkan dengan baik $(58,9 \%)$, hampir sebagian besar keluarga kurang memiliki pengetahuan tentang PHBS (54,2\%), hampir sebagian besar masyarakat memiliki sikap negatif tentang PHBS $(53,3 \%)$. Terdapat hubungan antara pengetahuan dengan PHBS ( $p$ value $=0,026)$, terdapat hubungan antara sikap dengan PHBS $(p$ value $=0,005)$. Peneliti menyarankan pihak puskesmas agar meningkatkan kegiatan promosi kesehatan tentang PHBS dengan melakukan penyuluhan kepada keluarga minimal satu bulan sekali dan mengadakan kegiatan gotong royong secara rutin satu bulan sekali, sebagai sarana pembelajaran PHBS kepada masyarakat.
\end{abstract}

Kata kunci : pengetahuan, sikap, perilaku, PHBS

\begin{abstract}
With the creation of healthy community life, of course, the main capital and assets are valuable to carry out the development. One way to realize a healthy society is to implement a clean and healthy living behavior $(P H B S)$ in a community environment. The purpose of this research is to know the factors that affect the behavior of clean and healthy living (PHBS) on the family in Muara Ciujung West Village of the working area of Rangkasbitung Puskesmas year 2018. This research is analytic with samples of 107 respondents taken using simple random sampling techniques. The results of the research are known to most of the families applying well (58.9\%), most families lack knowledge of PHBS (54.2\%), most people have a negative attitude about PHBS (53.3\%). There is a relationship between knowledge and PHBS ( $p$ value $=0.026$ ), there is a relationship between the attitude with PHBS ( $p$ value $=0.005)$. Researchers advise the puskesmas to increase health promotion activities about PHBS by conducting counseling to families at least once a month and holding mutual activities regularly once a month, as a means of learning PHBS to the community.
\end{abstract}

Keywords : knowledge, attitude, behavior, PHBS

Copyright (c) 2020 Deni Hermawan, Ucu Wandi Somantri

$\triangle$ Corresponding author

Address : Universitas Mathla'ul Anwar

ISSN 2721-9224 (Media Cetak)

Email : Ucuancayur@gmail.com

ISSN 2721-9216 (Media Online)

Phone :

DOI : https://doi.org/10.31004/abdidas.v1i4.66 


\section{PENDAHULUAN}

Ekspansi di bidang kesehatan bertujuan demi menambah kesadaran, kemampuan dan kesediaan hidup sehat bagi setiap penduduk Indonesia guna mewujudkan derajat kesehatan tertinggi. Sesuai dengan tujuan pembangunan berkelanjutan di dunia atau tujuan pembangunan yang dapat dilakukan. Beberapa tujuan yang berhubungan dengan lingkungan salah satunya termasuk perilaku hidup yang bersih dan sehat. Dengan kata lain, masyarakat diharapkan bertindak sebagai pelaku dalam pengembangan kesehatan dalam menjaga, menjaga dan meningkatkan kesehatannya sendiri, serta berperan aktif dalam mewujudkan kesehatan rakyatnya (Kemenkes RI, 2017).

Departemen Kesehatan melalui Gerakan Masyarakat Hidup Sehat ialah terorganisasi dan terjadwal tindakan yang dilakukan bersama-sama oleh semua komponen bangsa dengan kesadaran, kemauan dan kemampuan untuk berperilaku sehat untuk meningkatkan kualitas hidup. Implementasi Gerakan Masyarakat Sehat sering di kenal dengan sebutan GERMAS mau tak mau dimulai dari keluarga, lantaran keluarga merupakan bagian terkecil dari masyarakat yang membentuk kepribadian. GERMAS adalah gerakan nasional yang memprioritaskan upaya promotif dan preventif, tanpa prasangka terhadap upaya kuratif-rehabilitatif dengan melibatkan semua komponen bangsa dalam bersosialisasi dengan cara yang sehat (Ditjen Kesmas Kemenkes RI, 2017).
Perilaku bersih dan hidup sehat (PHBS) merupakan salah satu program promosi kesehatan pemerintah yang bertujuan untuk meningkatkan kemandirian masyarakat dalam menjaga dan meningkatkan kesehatan yang dikembangkan melalui lima tatanan yaitu tatanan rumah tangga, lembaga pendidikan, tempat kerja, ruang publik dan fasilitas kesehatan. Ada 10 indikator PHBS di rumah tangga yang menjalani persalinan dibantu oleh tenaga ahli medis, memberikan ASI eksklusif, menimbang bayi dan balita setiap bulan, menggunakan air bersih, menggunakan latticles, memberantas sarang nyamuk, mengonsumsi buah-buahan dan sayur-sayuran, melakukan aktifitas fisik setiap hari dan tidak merokok di rumah (Putri Lina, 2012).

Dinas Kesehatan Provinsi Banten sesuai dengan rencana strategi indikator kinerja Tahun 2017 dengan hasil capaian 77\% anggota rumah tangga perlu diberdayakan untuk melaksanakan Perilaku Hidup Bersih dan Sehat (Kinerja, 2017).

Pelaksanaan PHBS di rumah tangga dipengaruhi oleh beberapa faktor seperti pengetahuan tentang hidup bersih sehat serta dampak yang ditimbulkan apabila tidak berperilaku hidup bersih sehat. Pengetahuan dapat menjadikan seseorang memiliki kesadaran sehingga seseorang akan berperilaku sesuai pengetahuan yang dimiliki. Perubahan perilaku yang dilandasi pengetahuan, kesadaran dan sikap yang positif bersifat langgeng karena disadari oleh kesadaran mereka sendiri bukan paksaan (Putri Lina, 2012). Hal ini didukung oleh hasil penelitian (Erna \& Wahyuni, 2011) menjelaskan 
bahwa ada hubungan pengetahuan kesehatan lingkungan dengan perilaku hidup bersih dan sehat. Hal ini didukung oleh hasil Penelitian yang dilakukan oleh (Nurmy*edisio, 2013) bahwa pengetahuan dan sikap sangatlah penting agar keluarga mampu menerapkan perilaku hidup bersih dan sehat di tatatan rumah tangga.

Studi pendahuluan yang dilakukan oleh peneliti di dapat dari Puskesmas Rangkasbitung, menyatakan keluarga belum mampu menerapkan perilaku hidup bersih dan sehat. Dilihat dari angka kejadian diare selama tahun 2016 di Puskesmas Rangkasbitung, sebanyak 716 kasus dari jumlah target penemuan sebanyak 1.926 dan hasil wawancara terhadap 20 orang yang dilakukan 12 orang diantaranya mampu menerapkan perilaku hidup sehat dan menunjukan sikap yang baik untuk memperhatikan lingkungannya, adapun hal yang dilakukan dengan melahirkan dibantu oleh tenaga kesehatan, menimbang bayi secara rutin di posyandu, memberikan ASI, memberantas jentik dirumah serta memakan buah dan sayur. Namun ada 8 orang yang masih saja membiasakan merokok di dalam rumah, menggunakan air sungai untuk dimasak sehingga tidak bersih, kurang memperhatikan lingkungannya, ini dapat dilihat dari sampah berserakan di halaman rumah, air dalam bak mandi berwarna kekuningan dan bila dikonsumsi air yang tidak bersih sehingga terjadi angka kejadian diare sebanyak 37\% (Wardhani et al., 2020). Adapun tujuan penelitian ini adalah untuk mengetahui hubungan pengetahuan dan sikap dengan perilaku hidup bersih dan sehat pada keluarga di kelurahan Muara Ciujung Barat wilayah kerja Puskesmas Rangkasbitung tahun 2018.

\section{METODE}

Jenis penelitian adalah korelasional dengan pendekatan cross sectional. Populasi dalam penelitian ini adalah seluruh kepala keluarga di Kelurahan Mara Ciujung Barat Wilayah Kerja Puskesmas Rangkasbitung yaitu 3172 Kepala Keluarga pada Januari 2018. Teknik pengambilan sampel menggunakam probability sampling dengan jenis simple random sampling. Berdasarkan penghitungan rumus besar sampel dalam penelitian ini adalah 107 responden.

\section{HASIL DAN PEMBAHASAN}

\section{A. Hasil Analisis Univariat}

Tabel 1. Hasil Analisis Univariat

\begin{tabular}{lcc}
\hline PHBS & N & \% \\
\hline Kurang & 44 & 41,1 \\
\hline Baik & 63 & 58,9 \\
\hline Pengetahuan & $\mathbf{N}$ & $\mathbf{\%}$ \\
\hline Kurang & 58 & 54,2 \\
\hline Baik & 49 & 45,8 \\
\hline Sikap & $\mathbf{N}$ & $\mathbf{\%}$ \\
\hline Negatif & 57 & 53,3 \\
\hline Positif & 50 & 46,7 \\
\hline
\end{tabular}

Berdasarkan Tabel 1 dapat terlihat bahwa dari 107 kepala keluarga di Kelurahan Muara Ciujung Barat hampir sebagian besar atau sebanyak 44 keluarga belum menerapkan perilaku hidup bersih dan sehat (PHBS) dengan baik $(41,1 \%)$, hampir sebagian besar atau sebanyak 58 kepala keluarga kurang memiliki pengetahuan tentang perilaku hidup bersih dan sehat (PHBS) 
$(54,2 \%)$, hampir sebagian besar atau sebanyak 57 kepala keluarga memiliki sikap negatif tentang perilaku hidup bersih dan sehat (PHBS) $(53,3 \%)$.

\section{B. Hasil Analisis Bivariat}

Tabel 2. Hasil Analisis Bivariat

\begin{tabular}{lcc}
\hline \multicolumn{1}{c}{ Variabel } & P value & OR \\
\hline Pengetahuan dengan PHBS & 0,026 & 2,679 \\
\hline Sikap dengan PHBS & 0,005 & 3,393 \\
\hline
\end{tabular}

Dari tabel 2 dapat terlihat bahwa faktor pengetahuan dan sikap berhubungan dengan PHBS $(\mathrm{p}<0,05)$.

\section{Pembahasan}

\section{A. Analisa Univariat}

\section{Gambaran Perilaku Hidup Bersih dan Sehat (PHBS)}

Hasil penelitian menunjukkan bahwa hampir sebagian besar keluarga Kelurahan Muara Ciujung Barat melaksanakan perilaku hidup bersih dan sehat dengan baik $(58,9 \%)$. PHBS pada keluarga disebut PHBS tatanan rumah tangga, yaitu PHBS yang terdiri dari 10 indikator yang meliputi persalinan di tolong tenaga kesehatan; memberi bayi ASI eklusif; menimbang bayi setiap bulan; mencuci tangan dengan air bersih dan memakai sabun; menggunakan air bersih; menggunakan jamban sehat; memberantas jentik di rumah sekali seminggu; makan buah dan sayur setiap hari; melakukan aktivitas fisik setiap hari; tidak merokok di dalam rumah.

Hasil penelitian juga masih ditemukan hampir sebagian besar keluarga yang menerapkan PHBS dengan kurang baik $(41,1 \%)$. Kurangnya baiknya PHBS tersebut terlihat dari distribusi jawaban pada kuesioner PHBS, yaitu antara lain adalah persalinan tidak selalu ditolong tenaga kesehatan, tidak memberikan ASI Eksklusif pada bayinya, tidak memberikan ASI sampai anak berusia 2 tahun, tidak rutin menimbang bayi, tidak menggunakan air bersih yang mengalir untuk mencuci bahan makanan, tidak menggunakan air PAM/sumur pompa/air galon untuk memasak makanan, tidak mencuci tangan pakai sabun sebelum makan, tidak mencuci tangan pakai sabun setelah $\mathrm{BAB}$, tidak membersihkan jamban secara rutin, tidak menguras dan menyikat tempat penampungan air, menggantung pakaian dalam kamar, tidak setiap hari konsumsi sayur, tidak melakukan aktifitas fisik minimal 30 menit, dan merokok didalam rumah.

Masih kurang baiknya perilaku PHBS yang dilakukan hampir sebagian besar keluarga di Kelurahan Muara Ciujung Barat tersebut jika terus dilakukan dapat menimbulkan dampak yang merugikan bagi keluarga dan lingkungan sekitarnya. Salah satu contohnya adalah buang air besar tidak di jamban sehat, misalnya dikebun atau sungai. Hal tersebut dapat memicu terjadinya penyakit menular berbasis lingkungan seperti diare, penyakit kulit dan kecacingan. Seperti yang kita ketahui bahwa tinja atau kotoran manusia merupakan media sebagai tempat berkembang dan berinduknya bibit penyakit 
menular (misalnya; kuman/bakteri, virus dan cacing). Apabila tinja tersebut dibuang disembarangan tempat, misalnya kebun, sungai, dan lain-lain maka bibit penyakit tersebut akan menyebar luas ke lingkungan dan akhirnya akan masuk dalam tubuh manusia serta beresiko menimbulkan penyakit pada seseorang bahkan menjadi wabah penyakit pada masyarakat yang lebih luas.

Banyak faktor yang bisa menyebabkan keluarga kurang baik dalam menerapkan PBHS. Hasil wawancara dengan beberapa responden saat penelitian, menunjukan bahwa keluarga Kelurahan Muara Ciujung Barat secara pengetahuan hampir sebagian besar belum memahami sepenuhnya mengenai program PHBS, sehingga secara tindakan masih banyak keluarga tidak menerapkan PHBS dalam kehidupannya. Dari hasil tersebut tidak begitu heran jika masih terdapat keluarga tidak melakukan persalinan pada tenaga kesehatan, sebaliknya malah lebih memilih dukun kampung sebagai pilihan. Banyak keluarga yang menganggap bahwa persalinan sudah biasa ditangani oleh dukun kampung sehingga tidak harus ke bidan desa, hal ini dikarenakan telah menjadi kebiasaan turun menurun dari nenek moyang. Alasan yang lain karena menghormati pendapat orang tua, dan terakhir masalah ekonomi. Dari hasil observasi saat dilapangan juga diketahui bahwa masih terdapat keluarga yang lebih cenderung menjadikan sungai sebagai tempat buang air besar, bahkan mandi, serta dijadikan tempat cucian oleh ibu rumah tangga.

Berdasar hasil penelitian ini, peneliti berpendapat perlunya adanya strategi dan langkah konkrit untuk merubah perilaku keluarga sehingga dapat menerapkan PHBS yang baik. Salah satu hal yang bisa dilakukan adalah dengan melakukan promosi kesehatan dengan cara penyuluhan-penyuluhan secara langsung kepada masyarakat. Hal tersebut sesuai dengan pendapat Notoadmodjo yang menyatakan bahwa strategi promosi kesehatan merupakan determinan penting perilaku sehat dari masyarakat, keluarga, dan individu.

Promosi kesehatan sebagai program untuk meningkatkan perilaku sehat atau perilaku hidup bersih dan sehat (PHBS) dari masyarakat, keluarga, dan individu. Puskesmas sebagai sarana pelayanan kesehatan terdepan perlu meningkatkan kembali program-program promosi kesehatan dengan pemberdayaan kepada masyarakat. Pemberian informasi harus dilakukan terus menerus dan berkesinambungan, sehingga terdapat peningkatan pengetahuan pada masyarakat, selanjutnya masyarakat mau melakukan, dan pada akhirnya masyarakat mampu melaksanakan perilaku PHBS yang diharapkan (Putri Lina, 2012).

\section{Gambaran Pengetahuan Tentang PHBS}

Hasil penelitian menunjukkan bahwa hampir sebagian besar keluarga Kelurahan Muara 
Ciujung Barat Wilayah kurang memiliki pengetahuan yang memadai tentang PHBS $(54,2 \%)$. Menurut Notoatmodjo pengetahuan adalah merupakan hasil dari tahu, dan ini terjadi setelah seseorang melakukan penginderaan terhadap suatu objek tertentu. Pengetahuan terdiri dari sejumlah fakta dan teori yang memungkinkan seseorang dapat memahami sesuatu gejala dan memecahkan masalah yang dihadapinya (Putri Lina, 2012). Dalam penelitian ini adalah pengetahuan tentang PHBS khususnya PHBS dalam tatanan rumah tangga. Hal-hal tentang PHBS rumah tangga yang belum diketahui oleh hampir sebagian besar keluarga Kelurahan Ciujung Barat antara lain, persalinan sehat, jadwal dan manfaat penimbangan balita, syarat air bersih, mencuci tangan yang baik, syarat jamban sehat, cara pemberantasan nyamuk, manfaat konsumsi sayur dan buah, aktifitas fisik, dan dampak merokok.

Banyak faktor yang melatarbelakangi kurangnya pengetahuan tentang PHBS pada keluarga Kelurahan Muara Ciujung Barat, diantaranya adalah tingkat pendidikan, kurangnya sumber-sumber informal seperti dari media cetak maupun elektronik, dan juga kurangnya interaksi dengan petugas kesehatan. Dari hasil wawancara saat penelitian diketahui bahwa banyak kepala keluarga atau ibu rumah tangga yang berpendidikan rendah, bahkan ada yang tidak pernah bersekolah. Notoatmodjo menjelaskan bahwa pengetahuan dapat diperoleh dari pengalaman langsung, maupun dari pengalaman orang lain yang sampai kepadanya. Selain itu, dapat juga melalui media komunikasi, seperti radio, televisi, majalah, atau surat kabar (Putri Lina, 2012). Salah satu upaya untuk meningkatkan pengetahuan individu adalah melalui pendidikan dan pelatihan baik secara formal maupun informal. Dari hasil tersebut, dalam upaya meningkatkan pengetahuan keluarga tentang PHBS rumah tangga diperlukan peran serta dari tokoh masyarakat untuk memberikan pengertian tentang PHBS pada masyarakat, hal tersebut dapat dilakukan saat ada pertemuan-pertemuan dalam masyarakat, selain itu tokoh masyarakat harus menjadi role mode atau teladan bagi masyarakat dalam menerapkan PHBS yang baik dalam kehidupan sehari-hari. Selain hal tersebut, untuk petugas kesehatan kesehatan perlu meningkatkan promosi kesehatan kepada masyarakat dengan memperbanyak penyuluhan-penyuluhan tentang PHBS pada masyarakat.

\section{Gambaran Sikap Tentang PHBS}

Hasil penelitian menunjukkan hampir sebagian besar keluarga Kelurahan Muara Ciujung Barat memiliki sikap negatif tentang PHBS (53,3\%). Sikap negatif yang ditunjukkan hampir sebagian besar keluarga tersebut antara lain adalah setuju persalinan ditolong oleh dukun, setuju bahwa air hujan adalah sumber air bersih, setuju cuci tangan tidak menggunakan sabun, tidak setuju 
melakukan pemeriksaan jentik nyamuk secara berkala, setuju menggantung pakaian didalam kamar, tidak setuju jika tidak melakukan olah raga dapat menimbulkan gangguan fisik, tidak setuju jika tidak merokok, tidak setuju perokok pasif lebih beresiko terkena penyakit daripada perokok aktif, dan tidak setuju setiap rumah tangga harus melakukan PHBS.

(Putri Lina, 2012) menjelaskan bahwa sikap rnerupakan reaksi atau respon yang masih tertutup dari seseorang terhadap suatu stimulus atau objek. Manifestasi sikap tidak dapat langsung dilihat, tetapi hanya dapat ditafsirkan lebih dahulu dari perilaku yang tertutup. Terbentuknya sikap seseorang tidak terlepas dari pengetahuan atau informasiinformasi, dan pengalaman yang diperolehnya. Oleh sebab itu peran tokoh masyarakat dan tenaga kesehatan dalam hal ini sebagai penyampai informasi tentang PHBS sangat diperlukan.

Menurut (Gayatri Setyabudi \& Dewi, 2017), sikap merupakan pendapat maupun pandangan seseorang tentang suatu objek yang mendahului tindakannya. Sikap tidak mungkin terbentuk sebelum mendapat informasi, melihat atau mengalami sendiri suatu objek. Manusia dilahirkan dengan sikap pandangan atau sikap perasaan tertentu, tetapi sikap terbentuk sepanjang perkembangan. Peranan sikap dalam kehidupan manusia sangat besar. Bila sudah terbentuk pada diri manusia, maka sikap itu akan turut menentukan cara tingkah lakunya terhadap objek-objek sikapnya. Adanya sikap akan menyebabkan manusia bertindak secara khas terhadap objeknya.

Menurut peneliti, timbulnya sikap tidak mendukung pada keluarga terhadap PHBS disebabkan oleh kurangnya pengetahuan keluarga tersebut tentang PHBS. Seandainya keluarga sudah mengetahui dan mengerti tentang apa itu perilaku hidup bersih dan sehat (PHBS) rumah tangga dan manfaat melakukan PHBS rumah tangga, maka otomatis akan timbul pemikiran yang positif. Dari pemikiran positif tersebut akan menghasilkan suatu sikap yang positif juga yaitu mendukung dan setuju dalam hal tersebut dan selanjutnya mau melakukan upaya perilaku hidup bersih dan sehat (PHBS). Oleh sebab itu peran tokoh masyarakat dan petugas kesehatan sangat penting dalam hal mengajarkan serta memberi contoh yang baik dalam menerapkan perilaku hidup bersih dan sehat.

\section{B. Analisa Bivariat}

\section{Hubungan Pengetahuan Dengan PHBS}

Berdasar hasil analisis hubungan antara pengetahuan dengan perilaku PHBS pada keluarga Kelurahan Muara Ciujung Barat diketahui bahwa pada masyarakat dengan pengetahuan kurang, sebanyak 51,7\% berperilaku kurang baik dalam menerapkan PHBS. Sedangkan pada keluarga dengan pengetahuan baik, hanya terdapat $28,6 \%$ yang berperilaku kurang baik dalam menerapkan 
PHBS. Dari hasil tersebut terlihat bahwa keluarga yang memiliki pengetahuan baik lebih banyak yang berperilaku baik dalam menerapkan PHBS dibandingkan pada keluarga yang memiliki pengetahuan kurang.

Hasil uji statistik diperoleh nilai $\mathrm{p}=$ 0,026 pada $\alpha=0,05(\mathrm{p} \leq \alpha)$ yang berarti secara statistik terdapat hubungan yang bermakna antara pengetahuan dengan perilaku PHBS pada keluarga di Kelurahan Muara Ciujung Barat Wilayah Kerja Puskesmas Rangkasbitung Tahun 2018. Hasil analisis juga diperoleh nilai $\mathrm{OR}=2,679$, Artinya keluarga dengan pengetahuan kurang baik beresiko sebesar 2,679 kali lebih besar untuk berperilaku kurang baik dalam menerapkan PHBS rumah tangga dibandingkan masyarakat dengan pengetahuan yang baik.

Hal tersebut sesuai dengan yang kemukakan oleh (Putri Lina, 2012) yang mengatakan bahwa perilaku seseorang salah satunya dipengaruhi oleh faktor predisposisi. Faktor predisposisi merupakan faktor internal yang ada pada diri individu yang mempermudah untuk berperilaku, salah satunya adalah pengetahuan. Pengetahuan atau kognitif merupakan hal yang sangat penting untuk terbentuknya tindakan seseorang. Perilaku yang didasari oleh pengetahuan akan lebih langgeng daripada perilaku yang tidak didasari oleh pengetahuan.
Hasil penelitian ini sejalan dengan hasil penelitian (Kec \& Gelam, 2019) di Dusun II RW 04 Desa Sukakarya Kecamatan Sukakarya Kabupaten Bekasi mendapatkan hasil bahwa faktor pengetahuan berhubungan secara signifikan dengan PHBS rumah tangga menggunakan jamban sehat (nilai $\mathrm{p}=0,000$ ). Kemudian penelitian Kastari (2016) di wilayah kerja UPK Puskesmas Telaga Biru Keluarahan Siantan Hulu Pontianak Utara yang juga menemukan bahwa faktor yang berhubungan dengan pelaksanaan PHBS rumah tangga salah satunya adalah pengetahuan (nilai $\mathrm{p}=0,000$ ).

Menurut peneliti, pengetahuan sangat mempengaruhi perilaku seseorang, pengetahuan yang baik akan menciptakan perilaku yang baik pula termasuk dalam pelaksanaan PHBS. Semakin tinggi pengetahuan keluarga tentang PHBS maka keluarga tersebut akan semakin mengerti tentang pentingnya menerapkan PHBS dalam menjaga dan meningkatkan kesehatan anggota keluarga mereka, maka masyakarat akan termotivasi melakukan PHBS dengan baik.

\section{Hubungan Sikap Dengan PHBS}

Berdasarkan hasil analisis hubungan antara sikap dengan perilaku PHBS rumah tangga pada keluarga di Kelurahan Muara Ciujung Barat diketahui bahwa pada keluarga dengan sikap negatif, sebanyak $54,4 \%$ berperilaku kurang baik dalam menerapkan PHBS. Sedangkan pada keluarga dengan sikap 
positif, hanya terdapat $26 \%$ yang berperilaku kurang baik dalam menerapkan PHBS. Dari hasil tersebut terlihat bahwa pada keluarga yang memiliki sikap positif lebih banyak yang berperilaku baik dalam menerapkan PHBS dibandingkan pada masyarakat yang memiliki sikap negatif.

Hasil uji statistik diperoleh nilai $\mathrm{p}=$ 0,005 pada $\alpha=0,05(\mathrm{p} \leq \alpha)$ yang berarti secara statistik terdapat hubungan yang bermakna antara sikap dengan perilaku PHBS pada keluarga di Kelurahan Muara Ciujung barat Wilayah Kerja Puskesmas Rangkasbitung tahun 2018. Hasil analisis juga diperoleh nilai $\mathrm{OR}=3,393$, artinya keluarga dengan sikap negatif beresiko sebesar 3,393 kali lebih besar untuk berperilaku kurang baik dalam menerapkan PHBS dibandingkan pada masyarakat dengan sikap positif.

Hal tersebut sesuai dengan dikemukakan oleh (Putri Lina, 2012) yang mengatakan bahwa perilaku seseorang dipengaruhi beberapa faktor yaitu faktor predisposisi, faktor pemungkin, dan faktor pendorong. Faktor predisposisi merupakan faktor internal yang ada pada diri individu yang mempermudah untuk berperilaku, salah satunya adalah sikap. Sikap merupakan pendapat maupun pandangan seseorang tentang suatu objek yang mendahului tindakannya. Sikap tidak mungkin terbentuk sebelum mendapat informasi, melihat atau mengalami sendiri suatu objek. Manusia dilahirkan dengan sikap pandangan atau sikap perasaan tertentu, tetapi sikap terbentuk sepanjang perkembangan. Peranan sikap dalam kehidupan manusia sangat besar. Bila sudah terbentuk pada diri manusia, maka sikap itu akan turut menentukan cara tingkah lakunya terhadap objek-objek sikapnya. Adanya sikap akan menyebabkan manusia bertindak secara khas terhadap obyeknya, dalam hal ini sikap masyarakat terhadap pelaksanaan PHBS.

Hasil penelitian ini sejalan dengan hasil penelitian (Kec \& Gelam, 2019) di Dusun II RW. 04 Desa Sukakarya Kecamatan Sukakarya Kabupaten Bekasi mendapatkan hasil bahwa sikap berhubungan secara signifikan dengan PHBS rumah tangga menggunakan jamban sehat (nilai $\mathrm{p}=0,009$ ). Kemudian penelitian Kastari (2016) di wilayah kerja UPK Puskesmas Telaga Biru Keluarahan Siantan Hulu Pontianak Utara yang menemukan bahwa faktor yang berhubungan dengan pelaksanaan PHBS rumah tangga salah satunya adalah sikap (nilai $\mathrm{p}=0,000$ ).

Menurut teori perilaku disebutkan bahwa sebelum terbentuknya perilaku, didahului oleh pengetahuan dan sikap atau yang dikenal dengan konsep K-A-P (knowledge-attitudepractice) (Putri Lina, 2012). Berdasar teori tersebut dapat dijelaskan bahwa suatu sikap dipengaruhi oleh pengetahuan sebelum terwujud menjadi suatu tindakan. Dalam penelitian ini perilaku PHBS dipengaruhi 
oleh sikap tehadap PHBS tersebut, yang didasari oleh pengetahuan yang dimiliki oleh keluarga. Dari hasil ini dapat disimpulkan bahwa sikap keuarga dalam mendukung PHBS sangat penting dalam mendasari terbentuknya perilaku yang baik dalam penerapan PHBS. Berdasarkan hal tersebut keluarga harus mempertahankan sikap yang positif tersebut dengan cara meningkatkan pengetahuan yang dimilikinya, dengan pengetahuan yang baik dan sikap yang mendukung maka akan terbentuk perilaku yang baik dalam menerapkan PHBS dalam kehidupan sehari-hari.

\section{SIMPULAN}

Berdasarkan kerangka konsep penelitian, hasil penelitian, analisa data serta pembahasan yang mengacu pada tujuan penelitian, maka penulis menarik kesimpulan bahwa masyarakat Kelurahan Muara Ciujung Barat hampir sebagian besar memiliki perilaku PHBS dalam kategori baik $(58,9 \%)$, hampir sebagian besar memiliki pengetahuan tentang PHBS dalam kategori kurang $(54,2 \%)$, hampir sebagian besar memiliki sikap negatif tentang PHBS (53,3\%). Ada hubungan antara pengetahuan dan sikap dengan perilaku PHBS pada keluarga Kelurahan Muara Ciujung Barat Wilayah Kerja Puskesmas Rangkasbitung Tahun 2018.

Diharapkan petugas meningkatkan kegiatan promosi kesehatan tentang PHBS dengan melakukan penyuluhan kepada masyarakat minimal satu bulan sekali.

\section{DAFTAR PUSTAKA}

Ditjen Kesmas Kemenkes RI. (2017). GERMAS (Gerakan Masyarakat Hidup Sehat). Warta Kesmas, 1(1), 27 halaman. https://doi.org/0216-633X

Erna, I., \& Wahyuni. (2011). Gambaran Karakteristik Keluarga Tentang Perilaku Hidup Bersih Dan Sehat (PHBS) pada Tatanan Rumah Tangga di Desa Karangasem Wilayah Kerja Puskesmas Tanon II Sragen. Gaster : Jurnal Kesehatan, 8(2), 741-749. http://jurnal.stikesaisyiyah.ac.id/index.php/gaster/article/view/ 25

Gayatri Setyabudi, R., \& Dewi, M. (2017). Analisis Strategi Promosi Kesehatan dalam Rangka Meningkatkan Kesadaran Hidup Sehat oleh Rumah Sakit Jiwa Daerah Dr. RM. Soedjarwadi Provinsi Jawa Tengah. Jurnal Komunikasi, 12(1), 81-100. https://doi.org/10.20885/komunikasi.vol12.i $\underline{\text { ss1.art6 }}$

Kemenkes RI. (2017). PROFIL KESEHATAN INDONESIA TAHUN 2016 (Health Statistics). Kementerian Kesehatan RI, 431. www.kemkes.go.id

Putri Lina, H. (2012). Perilaku Hidup Bersih dan Sehat (PHBS) Siswa Di SDN 42 Korog Gadang Kecamatan Kuranji Padang.

Nurmy*edisio, A. (2013). Pengetahuan Dan Sikap Ibu Mengenai Prilaku Hidup Bersih Dan Sehat Di Kelurahan Koto Lalang. Kesehatan Masyarakat, 7(1), 2-9. 